Number 8

\title{
GAMBARAN KADAR KALSIUM DARAH PADA WANITA MENOPAUSE DI BANJAR BINOH KAJA, DESA UBUNG KAJA, KECAMATAN DENPASAR UTARA
}

\author{
Made Indah Kesuma Dewi ${ }^{1}$, IGA. Dewi Sarihati ${ }^{2}$, Cok. Dewi Widhya HS $^{3}$
}

\begin{abstract}
Background: Menopause women are one of the groups that have a high risk of osteoporosis, because at that time the amount of estrogen is reduced so that the absorption of calcium from the digestive tract will be reduced about 20-25\%. This is the reason why the level of calcium decreasing in blood. According to the initial observation at Banjar Binoh Kaja by researcher, from 10 menopause women, four of them are at risk of osteoporosis.

Methode: This study is a descriptive study which describes the blood calcium levels in menopause women at Banjar Binoh Kaja, Ubung Kaja Village, North Denpasar District, by doing measurement on their blood calcium concentration with $O$ - Cresolphthalein Complexon $(O C P C)$ method. The 34 respondents taken from total population of menopause women in age range 50-65 years. Respondent was selected using purposive sampling with criteria: menopause women in age range 50-65 years and not undergoing hormone replacement therapy.

Result: The results showed that the average concentration of blood calcium is $8,83 \mathrm{mg} / \mathrm{dL}$ which $11.76 \%$ respondents had low levels of blood calcium and $88.24 \%$ respondents had normal blood calcium levels. 33,33\% respondents in age range $62-65$ years and 66,67\% respondents in $16-20$ years periods of menopause has decrement of blood calcium levels.

Coclusion: The decrement of blood calcium levels mostly held in respondents in age range 62 - 65 years and respondents with 16-20 years periods of menopause.
\end{abstract}

Keywords: blood calcium, menopause.

\section{PENDAHULUAN}

Wanita yang telah mengalami menopause termasuk dalam golongan yang berisiko tinggi terhadap osteoporosis ${ }^{1}$ Pada masa tersebut jumlah hormon estrogen berkurang dan mengakibatkan terjadinya penurunan kadar kalsium darah ${ }^{2}$.

Hormon estrogen memiliki efek tidak langsung pada tubuh yaitu berperan dalam pengaturan keseimbangan kalsium dalam tubuh. Estrogen akan meningkatkan penyerapan kalsium di usus dan menurunkan pengeluaran kalsium dari ginjal sehingga kalsium di dalam darah dapat dipertahankan kadarnya ${ }^{3}$.

Menurut Hutton ${ }^{4}$, menurunnya kadar estrogen akan diikuti dengan penurunan penyerapan kalsium yang terdapat dalam makanan sehingga wanita yang mencapai masa menopause cenderung mengalami

\footnotetext{
1.,2.3., Jurusan Analis Kesehatan Poltekkes Denpasar Korespondensi : Made Indah Kesuma Dewi ${ }^{1}$, Jurusan Analis Kesehatan, Poltekes Denpasar, Jalan Sanitasi No. 1 Sidakarya, Denpasar-Bali 80224, Indonesia. Telp. +62-361-710 527, Fax. +62-361-710 448 Email : meditoryjournal@gmail.com
} 
pengurangan penyerapan kalsium sebanyak 20-25\%. Penyerapan kalsium dari saluran pencernaan yang berkurang mengakibatkan kalsium tulang akan diambil atau diserap untuk memenuhi kadar kalsium darah sehingga terjadilah pengeroposan tulang (osteoporosis) ${ }^{5}$.

Kalsium darah adalah kalsium yang berada dalam darah dan jaringan lunak. Kadar kalsium darah harus dikontrol dalam batas kadar yang sempit untuk mendapatkan fungsi fisiologinya yang normal ${ }^{6}$. Kalsium dalam darah atau cairan ekstraseluler (CES) berperan penting dalam proses fisiologis, yang meliputi kontraksi otot rangka, jantung dan otot polos, pembekuan darah, transmisi impuls saraf dan pembentukan tulang. Orang dewasa normal memiliki rentang konsentrasi kalsium plasma (darah) 2,2-2,6 $\mathrm{mmol} / \mathrm{L}$ atau 8,8-10,4 mg/dL ${ }^{7}$. Pemeriksaan kadar kalsium darah pada wanita menopause (dengan umur $\geq 50$ tahun) merupakan pemeriksaan yang hasilnya dapat digunakan dalam menentukan risiko teradinya osteoporosis $^{8}$.

\section{METODE}

Penelitian ini adalah penelitian deskriptif yaitu penelitian yang dilakukan untuk mendeskripsikan atau menggambarkan suatu fenomena di masyarakat atau memotret masalah kesehatan pada sekelompok penduduk atau orang yang tinggal dalam komunitas tertentu Populasi penelitian ini adalah seluruh wanita yang berumur 50-65 tahun di Banjar Binoh Kaja, Desa Ubung Kaja, Kecamatan Denpasar Utara yang berjumlah 137 orang. Besar sampel 34 orang yang ditentukan berdasarkan cara purposive sampling.

Data primer dikumpulkan dengan metode wawancara dan pemeriksaan laboratorium. Wawancara dilakukan untuk mengetahui nama responden, jenis kelamin responden, umur responden, lama menopause responden, konsumsi suplemen kalsium dan vitamin $\mathrm{D}$ responden, riwayat penyakit responden, pendidikan terakhir responden, dan pekerjaan responden. Kadar kalsium darah diukur melalui pemeriksaan laboratorium menggunakan alat Cobas Integra 400 Plus dengan metode $O_{-}$ Cresolphthalein Complexon (OCPC) di Laboratorium Patologi Klinik RSUP Sanglah Denpasar.

\section{HASIL DAN PEMBAHASAN}

\section{HASIL}

a. Hasil pemeriksaan kadar kalsium darah pada wanita menopause

Berdasarkan hasil analisis, diperoleh rata-rata kadar kalsium darah pada responden adalah sebesar 8,83 $\mathrm{mg} / \mathrm{dL}$, dengan kadar kalsium darah terendah adalah 
8,12 $\mathrm{mg} / \mathrm{dL}$ dan kadar kalsium darah tertinggi adalah 9,32 $\mathrm{mg} / \mathrm{dL}$.

Kadar kalsium darah pada wanita menopause menurut kategori dapat dilihat pada Tabel 1.
Kadar kalsium darah pada wanita menopause berdasarkan kelompok usia dapat dilihat pada Tabel 2.

Berdasarkan kelompok usia, dari 34 responden, kadar kalsium darah yang rendah

Tabel 1. Kadar Kalsium Darah pada Wanita Menopause

\begin{tabular}{|c|c|c|}
\hline Kadar Kalsium Darah $(\mathrm{mg} / \mathrm{dL})$ & Jumlah & Persentase $(\%)$ \\
\hline$<8,40$ & 4 & 11,76 \\
$8,40-9,70$ & 30 & 88,24 \\
$>9,70$ & 0 & 0 \\
\hline Total & 34 & 100 \\
\hline
\end{tabular}

Kadar kalsium darah yang diperoleh paling banyak ditemukan pada kelompok dari hasil pemeriksaan dibagi menjadi tiga usia 62-65 tahun, yaitu sebanyak 4 orang kategori, yaitu: rendah $(<8,40 \mathrm{mg} / \mathrm{dL}), \quad(33,33 \%)$.

Tabel 2. Kadar Kalsium Darah pada Wanita Menopause Berdasarkan Kelompok Usia

\begin{tabular}{|c|c|c|c|c|c|c|c|c|}
\hline \multirow{3}{*}{$\begin{array}{l}\text { Kelompok } \\
\text { Usia (th) }\end{array}$} & \multicolumn{6}{|c|}{ Kadar Kalsium Darah (mg/dL) } & \multirow{2}{*}{\multicolumn{2}{|c|}{ Total }} \\
\hline & \multicolumn{2}{|c|}{$<8,40$} & \multicolumn{2}{|c|}{$8,40-9,70$} & \multicolumn{2}{|c|}{$>9,70$} & & \\
\hline & $\sum$ & $\%$ & $\sum$ & $\%$ & $\sum$ & $\%$ & $\sum$ & $\%$ \\
\hline $50-53$ & 0 & 0 & 5 & 100 & 0 & 0 & 5 & 100 \\
\hline $54-57$ & 0 & 0 & 8 & 100 & 0 & 0 & 8 & 100 \\
\hline $58-61$ & 0 & 0 & 9 & 100 & 0 & 0 & 9 & 100 \\
\hline $62-65$ & 4 & 33,33 & 8 & 66,67 & 0 & 0 & 12 & 100 \\
\hline
\end{tabular}

normal $(8,40-9,70 \mathrm{mg} / \mathrm{dL})$, dan tinggi $(>9,70$ $\mathrm{mg} / \mathrm{dL})$. Berdasarkan hasil penelitian, sebagian besar responden memiliki kadar kalsium darah yang normal yaitu sebanyak 30 orang $(88,24 \%)$.

b. Kadar kalsium darah pada wanita menopause berdasarkan kelompok usia c. Kadar kalsium darah pada wanita menopause berdasarkan lama menopause

Kadar kalsium darah pada wanita menopause di berdasarkan lama menopause dapat dilihat pada Tabel 3 . 
Tabel 3.Kadar Kalsium Darah pada Wanita Menopause Berdasarkan Lama Menopause

\begin{tabular}{|c|c|c|c|c|c|c|c|c|}
\hline \multirow{2}{*}{$\begin{array}{c}\text { Lama } \\
\text { Menopause }\end{array}$} & \multicolumn{6}{|c|}{ Kadar Kalsium Darah (mg/dL) } & \multicolumn{3}{|c|}{ Total } \\
\cline { 2 - 8 }$($ th) & \multicolumn{2}{|c|}{$<8,40$} & \multicolumn{2}{|c|}{$8,40-9,70$} & \multicolumn{2}{|c|}{$>9,70$} & \multicolumn{3}{|c|}{} \\
\cline { 2 - 8 } & $\sum$ & $\%$ & $\sum$ & $\%$ & $\sum$ & $\%$ & $\sum$ & $\%$ \\
\hline $1-5$ & 0 & 0 & 8 & 100 & 0 & 0 & 8 & 100 \\
$6-10$ & 0 & 0 & 7 & 100 & 0 & 0 & 7 & 100 \\
$11-15$ & 0 & 0 & 13 & 100 & 0 & 0 & 13 & 100 \\
$16-20$ & 4 & 66,67 & 2 & 33,33 & 0 & 0 & 6 & 100 \\
\hline
\end{tabular}

Berdasarkan lama menopause, dari 34 responden, kadar kalsium darah yang rendah paling banyak ditemukan pada wanita menopause yang telah mengalami menopause selama 16-20 tahun, yaitu sebanyak 4 orang $(66,67 \%)$.

\section{Pembahasan}

Rata-rata dari seluruh hasil pemeriksaan kadar kalsium darah pada wanita menopause adalah $8,83 \mathrm{mg} / \mathrm{dL}$ yang tergolong kategori normal. Hasil penelitian pada Tabel 1 menunjukkan bahwa 11,76\% responden memiliki kadar kalsium darah yang rendah, 88,24\% responden memiliki kadar kalsium darah yang normal, dan $0 \%$ responden memiliki kadar kalsium darah yang tinggi. Hal ini menggambarkan bahwa lebih banyak wanita menopause yang memiliki kadar kalsium darah yang normal. Hasil ini sejalan dengan penelitian yang dilakukan di Pk. St. Corolus Jakarta Timur, dimana sebagian besar wanita menopause yang diteliti mempunyai kadar kalsium darah yang normal yaitu sebanyak $61,82 \%^{8}$. Berbeda halnya dengan hasil penelitian yang dilakukan di RW 03 Kelurahan Sendangmulyo, Kecamatan Tembalang, Semarang, dimana diperoleh hasil kadar kalsium darah pada wanita menopause yang diteliti cenderung rendah yaitu sebanyak $69,23 \%$ dan hanya $30,77 \%$ yang memiliki kadar kalsium darah yang normal ${ }^{9}$.

Kadar kalsium darah yang normal disebabkan karena metabolisme kalsium di dalam tubuh berjalan normal dan tidak adanya gangguan pada faktor-faktor yang mempengaruhi kadar kalsium darah tersebut. Menurut Sauberlich $^{10}$, kadar kalsium serum dikontrol secara ketat oleh berbagai faktor termasuk asupan gizi yang diterima oleh tubuh. Selain itu, kontrol juga dilakukan oleh $1,25-$ dehidroxycholecalsiferol, hormon paratiroid, kalsitonin, fosfor, protein, dan estrogen. 
Penurunan kadar kalsium darah dapat terjadi apabila terdapat ketidakseimbangan diantara faktor-faktor tersebut. Salah satunya adalah penurunan kadar hormon estrogen secara bertahap yang dialami oleh wanita menopause. Hormon estrogen memiliki efek tidak langsung pada tubuh yaitu berperan dalam pengaturan keseimbangan kalsium dalam tubuh. Estrogen akan meningkatkan penyerapan kalsium di usus dan menurunkan pengeluaran kalsium dari ginjal sehingga kalsium di dalam darah dapat dipertahankan kadarnya ${ }^{11}$.

Penurunan kadar kalsium darah terjadi pada wanita menopause kelompok usia tertinggi, yaitu kelompok usia 62-65 tahun. Hasil analisis terhadap kadar kalsium darah dari 34 responden diperoleh kadar kalsium darah terendah adalah sebesar $8,12 \mathrm{mg} / \mathrm{dL}$ yang ditemukan pada responden yang berusia 65 tahun, sedangkan kadar kalsium darah tertinggi (namun masih dalam batas normal) yaitu 9,32 $\mathrm{mg} / \mathrm{dL}$ ditemukan pada responden yang berusia 50 tahun. Hasil ini menggambarkan bahwa semakin tinggi usia maka kadar kalsium darah akan mengalami penurunan. Hasil ini senada dengan penelitian yang dilakukan di Panti Sosial Tresna Werdha Wana Seraya Denpasar, dimana pemeriksaan kadar kalsium darah terhadap wanita menopause usia 50-60 tahun menunjukkan penurunan kadar kalsium darah paling banyak terjadi pada wanita menopause yang berusia 60 tahun $^{12}$.

Kemampuan tubuh menyerap kalsium dari makanan semakin menurun dengan semakin bertambanya usia $^{13}$. Laju kehilangan kalsium akan meningkat cepat pada wanita pascamenopause (tiga sampai tujuh tahun setelah menopause) dikarenakan kekurangan hormon estrogen. Hutton menjelaskan bahwa, menurunnya kadar estrogen akan diikuti dengan penurunan penyerapan kalsium yang terdapat dalam makanan sehingga wanita yang mencapai masa menopause cenderung mengalami pengurangan penyerapan kalsium sebanyak $20-25 \%{ }^{4}$.

Penurunan kadar kalsium darah ditemukan pada wanita menopause dengan rentang lama waktu menopause 16-20 tahun. Hasil analisis terhadap kadar kalsium darah dari 34 responden diperoleh kadar kalsium darah terendah adalah sebesar $8,12 \mathrm{mg} / \mathrm{dL}$ yang ditemukan pada responden yang memiliki rentang lama waktu menopause 19 tahun, sedangkan kadar kalsium darah tertinggi (namun masih dalam batas normal) yaitu $9,32 \mathrm{mg} / \mathrm{dL}$ ditemukan pada responden yang memiliki rentang lama waktu menopause 1 tahun. Hasil ini menggambarkan bahwa kadar kalsium darah yang rendah terjadi pada wanita menopause yang mempunyai rentang lama waktu menopause yang panjang. Semakin lama 
waktu menopause maka kadar hormon estrogen juga akan semakin berkurang. Penurunan hormon estrogen akan berpengaruh pula pada efektivitas penyerapan kalsium di usus dan tentunya kadar kalsium darah dalam tubuh juga dapat berkurang.

Produksi hormon estrogen tidak akan berhenti secara tiba-tiba pada awal menopause karena tidak terjadi kerusakan pada indung telur ${ }^{14}$. Produksi hormon estrogen akan berangsur-angsur berkurang dan penurunan ini akan memakan waktu yang cukup lama dan bertahap. Berkurangnya kadar hormon estrogen akan mengganggu penyerapan kalsium yang akan mempengaruhi kadar kalsium darah sehingga akan menggangu proses pembentukan tulang dan fungsi kerja dalam tubuh lainnya. Rendahnya hormon estrogen dalam jangka panjang akan menimbulkan ancaman osteoporosis (pengeroposan tulang) yang membuat mudahnya terjadi patah tulang. Penelitian menunjukkan, $37,3 \%$ terjadinya osteoporosis dialami oleh wanita $>40$ tahun yang sudah menopause dan $6 \%$ pada wanita yang belum menopause ${ }^{15}$.

\section{SIMPULAN DAN SARAN}

\section{Simpulan}

Wanita menopause di Banjar Binoh Kaja, Desa Ubung Kaja, Kecamatan Denpasar
Utara memiliki rata-rata kadar kalsium darah sebesar $8,83 \mathrm{mg} / \mathrm{dL}$, dimana $11,76 \%$ responden memiliki kadar kalsium yang rendah dan 88,24\% responden memiliki kadar kalsium darah yang normal. Kadar kalsium darah yang rendah paling banyak ditemukan pada kelompok usia 62-65 tahun yaitu sebesar 33,33\%. Kadar kalsium darah yang rendah ditemukan pada kelompok responden dengan lama waktu menopause 16-20 tahun yaitu sebesar $66,67 \%$.

\section{Saran}

Perlu dilakukan penelitian lebih lanjut dengan mengontrol faktor-faktor risiko lain yang dapat mempengaruhi kadar kalsium darah, seperti asupan makanan, aktivitas fisik, kebiasaan merokok, kebiasaan konsumsi alkohol dan kafein, serta penyakit lain yang dapat mempengaruhi kadar kalsium darah.

\section{DAFTAR PUSTAKA}

1. Akmal, M., dkk, Ensiklopedi Kesehatan Untuk Umum, Yogyakarta: AR-RUZZ MEDIA, 2010.

2. Febriani, R. Hubungan Tingkat Pengetahuan Osteoporosis Dengan Perilaku Pencegahan Osteoporosis Pada Wanita Pre-Menopause Di Kelurahan Jebres Surakarta, (online), available:

[http://dglib.uns.ac.id/pengguna. php?mn= showview\&id=2926], $(22$ Januari 2014), 2010

3. Purnamasari, D., Ensiklopedia Praktis Kesehatan: Mendeteksi Gejala Penyakit - Penyakit Umum 
Bagi Orang Awam dan Penanggulangannya, Yogyakarta: Pustaka Radja. 2011

4. Kuntjoro, Z.S., Menopause, (online), available: [http://www.epsikologi.com/artikel/lanjut-

usia/menopausel, (22 Januari 2014). 2002.

5. Waluyo, S., 100 Questions\&Answers: Menopause atau Mati Haid, Jakarta: PT. Elex Media Komputindo. 2010.

6. Imron S., Gambaran Pemeriksaan Kalsium Darah dan Urine Pada Lansia yang Ikut Senam di Sasana kyai Saleh Semarang, (online), available [http:digilib.unimus.ac.id] November 2013). 2009.

7. Guyton, A.C. dan Hall J.E., Buku Ajar Fisiologi Kedokteran, Alih Bahasa : Irawati, dkk., Edisi 11, Jakarta : Penerbit Buku Kedokteran EGC.2007.

8. Aruan dan Apryana, Gambaran Kalsium Darah Pada Wanita Menopause, (online), available: [http://library.thamrin.ac.id/index.ph $\mathrm{p} ? \mathrm{p}=$ show_detail\&id $=1588] \quad$ (22 Januari 2014). 2011.

9. Tyas, A.C., Gambaran Kalsium Darah Pada Wanita Menopause , (online), available: [http://digilib.unimus.ac.id/files/disk 1/125/jtpunimus-gdl-apriliyaca6213-1-babi.pdf], (22 Desember 2013), 2011.

10. Suryono, dkk., Pengaruh Pemberian Susu Terhadap Kadar Kalsium Darah dan Kepadatan Tulang Remaja Pria, Media Gizi dan Keluarga,Juli 2007 31(1): p.6370.2007 .

11. Purnamasari, D., Ensiklopedia Praktis Kesehatan: Mendeteksi Gejala Penyakit - Penyakit Umum

Meditory | Vol. 4, No.2, Desember 2016
Bagi Orang Awam dan Penanggulangannya, Yogyakarta: Pustaka Radja. 2011.

12. Fridayani, I., Pemeriksaan Kalsium Pada Wanita Usia 50-60 Tahun, Karya Tulis Ilmiah tidak diterbitkan, Denpasar: Jurusan Analis Kesehatan STIKes Wira Medika.2011.

13. Waluyo, S., 100 Questions\&Answers: Menopause atau Mati Haid, Jakarta: PT. Elex Media Komputindo.2010.

14. Wirakusumah, E.S., Menopause, Jakarta: Gramedia Pustaka Utama.2003.

15. Tsania, N., Faktor-Faktor yang Berhubungan dengan Kejadian Osteoporosis Pada Kelompok Usia 40 Tahun Keatas di Lima Puskesmas Kecamatan Sukmajaya Kota Depok tahun 2008, (online), available

[http://lontar.ui.ac.id/file?file=digital /125633-S-5641-Faktorfaktor\%20osteoporosis-Hasil.pdf], (6 Pebruari 2014).2008. 
